\title{
Effects of Manganese and Iron Organic Sources in Layer Diets on Nutritional Quality of Eggs
}

\author{
Gabriela M. CORNESCU*1), Horia GROSU ${ }^{1)}$, Arabela E. UNTEA ${ }^{2)}$, Tatiana D. PANAITE ${ }^{2)}$, \\ Anca BERCARU ${ }^{2)}$ \\ ${ }^{1)}$ University of Agronomic Science and Veterinary Medicine, 59 Marasesti, Bucharest, Romania \\ ${ }^{2)}$ National Institute for Research Development in Animal Biology and Nutrition, 1 Bucuresti Road, \\ Balotesti, 077015 Ilfov, Romania \\ *Corresponding author, email: gabriela_cornescu@yahoo.com
}

Bulletin UASVM Animal Science and Biotechnologies 71(2) / 2014,

Print ISSN 1843-5262; Electronic ISSN 1843-536X

DOI:10.15835/buasvmcn-asb:10571

\begin{abstract}
Organic trace minerals present a higher bioavailability and stability, therefore lower rates of inclusion in feed will be needed to meet the poultry nutritional requirements which will lead to a lower environmental output. The purpose of this study was to determine the effect of total replacement of the inorganic Mn and Fe salts by organic forms of these elements on nutritional quality of eggs and on apparent absorption coefficients. The study was conducted on 192 laying hens, 2 birds/cage, divided into 3 groups $\left(C, E_{1}, E_{2}\right.$ ). All groups received a similar diet (17.96\% crude protein (CP) and $2724.31 \mathrm{kcal} / \mathrm{kg}$ metabolizable energy (ME). Diet $\mathrm{E}_{1}$ used the same level of Mn and Fe as diet C, but in chelated form (71.9 mg Mn/kg and $60 \mathrm{mg} \mathrm{Fe} / \mathrm{kg}$ ). Compared to C, diet $\mathrm{E}_{2}$ had the same level of Fe (inorganic source) but the Mn concentration was $200 \mathrm{mg} / \mathrm{kg}$ (organic source). Every two weeks, egg samples were collected randomly (18 eggs/group). All droppings were daily collected in order to form average weekly samples/ cage, from which $\mathrm{Mn}, \mathrm{Fe}$ was determined by FAAS. The analytical results showed a significant $(\mathrm{P} \leq 0.05)$ increasing of Mn concentration in egg yolk for $\mathrm{E}_{2}(1.84 \pm 0.28 \mathrm{mg} / \mathrm{kg})$ compare to $\mathrm{C}(1.46 \pm 0.16 \mathrm{mg} / \mathrm{kg})$ and $\mathrm{E}_{1}(1.59 \pm 0.30 \mathrm{mg} /$ $\mathrm{kg}$ ). The apparent absorption coefficients of Fe and $\mathrm{Mn}$ were higher for $\mathrm{E}_{2}$ compare to the other two groups ( $\mathrm{E}_{1}$, C). A possible explanation of these results could be the existent interactions between the trace elements found in animal organism, a high concentration of Mn being able to influence positively the absorption of Fe in organism. The chelate source of trace minerals can be a way of obtaining Mn enrichment eggs but only using amounts of Mn above conventional rate.
\end{abstract}

Keywords: chelated minerals, egg quality, Fe, laying hens, $\mathrm{Mn}$

Introduction. Chelates benefits consist of greater physical stability, which reduces the separation of trace elements and vitamins in feed oxidation and increases their adoption (Stanacev et al., 2013). Some authors noticed no differences between inorganic and organic sources of $\mathrm{Mn}$ or Zn (Swiatkiewicz and Koreleski, 2008), others suggested that use of organic sources of $\mathrm{Mn}$ substantially affects laying performance and eggshell quality (Sun et al., 2012). However, there is an impairment of iron absorption when high levels of manganese are fed (Baker \& Halpin, 1991).

Aims and objectives. The purpose of thisstudy was to determine the effect of total replacement of the inorganic $\mathrm{Mn}$ and Fe salts by organic forms of these elements ( $C$ and $E_{1}$ ). For E2, the effects of organic Mn supplementation and an inorganic form of Fe were studied on the nutritional quality of eggs and on apparent absorption coefficients.

Materials and methods. A study was carried out on 192 Lohmann Brown laying strain, divided into 3 groups of 32 cages/group ( 2 hens/cage), in an experimental house provided with digestibility cages. All groups received a similar diet $(17.96 \%$ $\mathrm{CP}$ and $2724.31 \mathrm{kcal} / \mathrm{kg} \mathrm{ME}$ ). Diet $\mathrm{E}_{1}$ used the same level of $\mathrm{Mn}$ and $\mathrm{Fe}$ as diet $\mathrm{C}$, but in chelated form (71.9 mg Mn/kg and $60 \mathrm{mg} \mathrm{Fe} / \mathrm{kg}$ ). Compared to C, $\operatorname{diet} E_{2}$ had the same level of Fe (inorganic source) but the Mn concentration was $200 \mathrm{mg} / \mathrm{kg}$ (organic source). During the study, all droppings were daily collected in order to form average weekly 
Tab. 1. Apparent coefficients absorption (\%) of minerals from ingesta (average values/group)

\begin{tabular}{ccccc}
\hline & Balance parameters & $\mathrm{C}$ & $\mathrm{E}_{1}$ & $\mathrm{E}_{2}$ \\
\hline Manganese & Ingested (g/hen/day) & $23.26 \pm 2.18$ & $21.01 \pm 2.74$ & $34.36 \pm 5.02$ \\
\cline { 2 - 5 } & Excreted (g/hen/day) & $19.26 \pm 3.21$ & $17.60 \pm 3.02$ & $26.47 \pm 2.94$ \\
\cline { 2 - 5 } Iron & Absorption (\%) & $17.19 \pm 1.05^{\mathrm{c}}$ & $16.25 \pm 1.54^{\mathrm{c}}$ & $22.91 \pm 3.07^{\mathrm{a}, \mathrm{b}}$ \\
\cline { 2 - 5 } & Ingested (g/ hen/day) & $53.28 \pm 5.27$ & $53.10 \pm 6,41$ & $55.05 \pm 6.01$ \\
\cline { 2 - 5 } & Excreted (g/hen/day) & $33.65 \pm 6.07$ & $31.69 \pm 5.21$ & $32.03 \pm 7.13$ \\
\cline { 2 - 5 } & Absorption (\%) & $36.82 \pm 4.82$ & $40.28 \pm 5.42$ & $41.82 \pm 6.02$ \\
\hline
\end{tabular}

$\mathrm{a}$ = significantly different from $\mathrm{C} ; \mathrm{b}$ = significantly different from E1; $\mathrm{c}$ = significantly different from $\mathrm{E} 2$

samples/cage. The following characteristics were evaluated: feed intake, feed conversion, production, eggs weight, egg shell thickness and egg shell breaking strength. At the beginning of the experiment and in the final experimental week 18 eggs/group were collected, 6 samples/group of shell and yolk were analyzed for: dry matter, ash, $\mathrm{Mn}$ and Fe according to Regulation (EC) no. $152 / 2009$.

Results and discussion. Table 1 presents data concerning the amount of manganese ingested/ excreted and the absorption coefficients, for E2 group compared to $\mathrm{C}$ and $\mathrm{E} 1$, calculated according to total collection technique described by Ajmal Khan (2003).

The absorption coefficient for $\mathrm{Mn}$ was significantly higher for $\mathrm{E}_{2}$ compared to $\mathrm{C}$ and $\mathrm{E} 1$. Using the same level of $\mathrm{Fe}$ concentration for all three groups, but the varied sources: $\mathrm{E}_{1}$ (organic source) and $C, E_{2}$ (inorganic source), the apparent coefficients of iron registered the highest value for

a
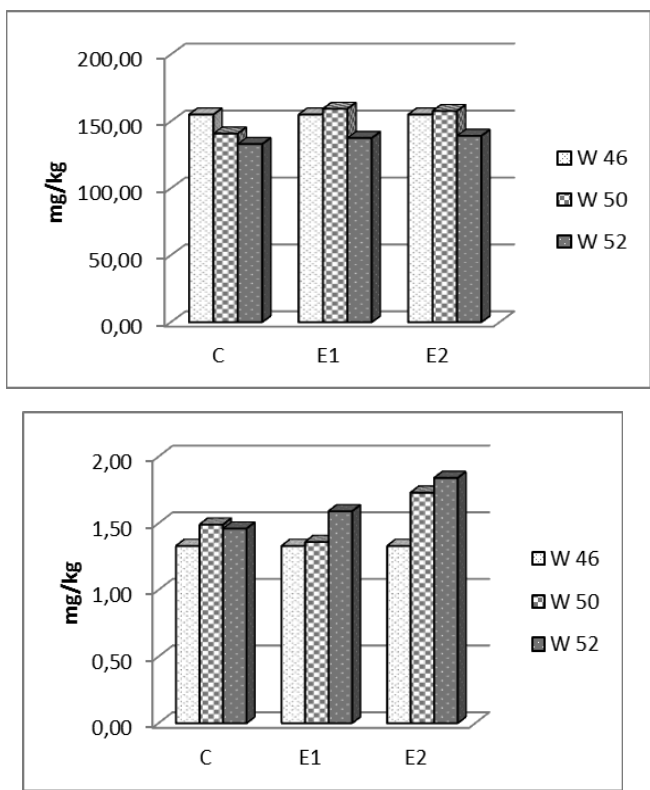

Fig. 1. Iron (a) and manganese (b) concentrations in egg yolk during the experimental period
$\mathrm{E}_{2}$ group, but the results are without any statistically significance. At the end of experiment, the analytical results showed an improvement of nutritional quality of eggs in terms of significant $(\mathrm{P} \leq 0.05)$ increasing of $\mathrm{Mn}$ concentration in egg yolk for $E_{2}(1.84 \pm 0.28 \mathrm{mg} / \mathrm{kg})$ compare to $C$ $(1.46 \pm 0.16 \mathrm{mg} / \mathrm{kg})$. No statistically differences were registered for $\mathrm{Fe}$ concentrations in yolk samples.

Conclusion. The apparent absorption coefficient of $\mathrm{Mn}$ was higher for $\mathrm{E}_{2}$ compare to the $\mathrm{C}$. The chelate source of trace minerals can be a way of obtaining Mn enrichment eggs but only using amounts of Mn above conventional rate.

Acknowledgements. This paperwas published under the frame of European Social Found, Human Resources Development Programme 2007-2013, project no. POSDRU/159/1.5/ S/132765.

\section{REFERENCES}

1. Ajmal Khan M, Mahr-Un-Nisa, Sarwar M (2003). Techniques measuring digestibility for the nutritional evaluation of feeds. Int. J. Agri. Biol. 5(1): 91-94.

2. Baker DH and Halpin KM (1991). Manganese and iron interrelationship in the chick. Poultry Sci 70:146-152.

3. Stanacev V, Puvaca N, Milic D, Stanacev V, Drinic M (2013). Microelements and their chelate forms in nutrition of monogastric animals: a review. Scientific Papers. Series D. Animal Science, LVI: 90-96.

4. Sun Q, Guo Y, Li J, Zhang T, Wen J (2012). Effects of methionine hydroxy analog chelated $\mathrm{Cu} / \mathrm{Mn} / \mathrm{Zn}$ on laying performance, egg quality, enzyme activity and mineral retention of laying hens. Journal of Poultry Science 49:2025.

5. Swiatkiewicz S, Koreleski J (2008). The effect of zinc and manganese source in the diet for laying hens on eggshell and bones quality. Veterinarni Medicina 53:555-563. 